特異な経過をたどった自閉的精神遅滞

の 1 症例について

薄 井省 吾*.平井保 男 * . 古 元 順子*

脳器質的背景の明僚な成人自閉症の経過を長期継続的に追跡して、その症状・経過の特異性を明らかにし、これら を脳病理、精神病理の両面より考察した。特記すべき事項を列記すると次のとおりである。生後 7 力に発症した臨 床的てんかんの発作は服薬により 6 歳以後抑圧されており、一貫して脳波上上連続性・発作性異状が存在し、 $\mathrm{C} T$ 上 左側頭深部に高吸収巣を認める。この左側頭深部の病巣とてんかんとの関連は不詳であり、発作型、脳波所見など より本例を側頭葉てんかんとするには理由がそしい。本例の折れ線型経過及び思春期に発生した特異な慢性分裂病様 過程と脳病理所見などとの関連について考察し、多動性、感情易変性・発作的暴力行為などをシュトラウス症候群と 自閉症候群との連続線上に定位した。また本症の最強度の固執性、反響語・遅延反響語の欠如、遅延性攻撃行動な どの特異性を指摘し、精神遅滞度の推移についても言及した。

\section{I .はじめに}

自閉症は現在のところ症候群 1)22)27)36) と考えられて おり、その症状、経過、転起にもかなりの幅がある。長 期予後 5)13(19)20)24)25)30)32)も大体に判っており、最終的にさ まざまな程度の精神遅滞状態にとどまるものが大部分で ある。さて処遇との関連において長期に追跡した事例 334 を積重るることも、特異な症例 23)を検討することも他の 研究方法と並んで自閉症解明の重要な手法であると考之 られる。われわれは、自閉症候群に属する特異な症状、 経過をもった精神遅帯の一症例を、相当精細に長期間追 跡したので、ここに報告しいささか考察を加えることに する。

\section{II. 症例 U.A. 令}

\section{(1) 家族歴及U゙家族環境}

父27歳、母 25 歳、兄 3 歳の時第 2 子として出生した。父， は、農、商を兼業し経済状態は中程度。性格は律義、几 帳面であるがやや可親性に乏しい。母は均衡のとれた性 格で兄は知能、性格とも普通で患児に対しては幾分無関 心である。養育態度は総合的にみてやや甘いが特別な偏 クはなく夫婦間に緊張もない。負因としては父の従兄に 分裂病質または欠陷分裂病らしい人があるが詳細は不明。

（2）生活史及U゙症歴

妊娠中母は概して健康で、満期産の出産経過は順調で あったが腤带捲絡、軽度仮死が認められている。生下時

* 岡山大学
体重は $3250 \mathrm{~g}$ 、栄養は混合栄養。定頝 3 力月、這い始め 9 力月、始歩 14 力月、その後の身体発育及び運動機能の 発達は正常であったが精神発達の面では人見知りは乏し かった模様。始語は大体 1 墄過でその後も比較的順調に 語数が増しており、18カ月頃には歌らしいものも存在し た。対人接触もある程度あり、2 歳前後には芸事を要求 されると「オツムテンテン、アワアワ」などをすること ができ、遊びに来る近所の子を余りいやがらなかった。 ただし巻き尺、水遊びに対する異常固執性が 1 歳過ぎよ ク出現しているが、それ以外に家人は精神発達の異常を ほとんど認めていない。その後、2 墄半ばから言葉も对 人接触も乏しくなり始め、明瞭な自閉的退行が始まった と推定される。しかし基本的生活習慣は多少遅れ気味な 速度で成立している。感覚・知覚面での特別な偏倚は認め られていない。なお3 歳児検診において「知恵おくれ」と言 われた。7カ月頃初めて短いけいれん発作が気付かれて いる。月に $3 \cdot 4$ 回程度の頻度で同様な発作が続いてお ク、2 歳の頃某大附属病院で精查を受け、脳波上棘波を 含む発作性異常波が存在したが明瞭な焦点は認められて いない。臨床的てんかんと診断されたがその後の服薬は 不規則で前述のような発作が年 5ー6 回程度起きていた。 幼稚園（5 歳）を経て 6 歳で某大教育学部附属養護学校 (附養と略す)に入学。学校側の指導で某大附属病院神経. 精神科の診療を受け、症状（精神症状も含めた）に応じ た適切な薬物管理を継続し、以来てんかん発作は引続き 抑制されている。脳波検查は年 1 回程度施行され、昭和 56年 7 月服薬中の脳波においても 9 〜 $10 \mathrm{~Hz} の 风 に$ — $7 \mathrm{~Hz}$ の徐波が多く混在する背景波に棘徐波結合を含む 
発作波が出現しており、連続性・発作性異常が併存する 症状てんかんの所見が明瞭であったが焦点は認められな かった。

全経過を通じて、脳波上の明瞭な非対称、焦点も精神 運動発作、精神発作など側頭葉てんかんを示唆する発作 毛確認されていない。昭和56年 9 月のC Tにおいて、ぺ ンタゴンの左側に比較的小さい高吸収巣が相接して 3 コ 認められ、左シルビウス溝奥の側頭葉深部の位置にあた ク、出産時などの病理的変化が石灰化したものと推定さ れる。幼稚園、学校生活を通じ程度に変動はあったが、 一貫して集団順応が困難であったと言える。

附盖入学以後同校在学中は教師、主治医、家庭は密接 に連絡し合い、協力して経過の推移に可能な限りの対応 と治療教育を行なった。すなわち内的興奮の度に応じて 向精神薬の質量を適切に加減したことは言うまでもなく、 9 １0歳頃身体接触を求めていることを洞察し、欲求を 充足させ、ある程度有効であったことなどを例としてあ げておく。前述の生後30力月頃より始まったと推定され る明瞭な自閉的退行により言語、对人接触が著しく減少 し、興味の偏在、常同性、強迫的固執性も増強、気分易 変性、多動性、興奮衝動性などが出現し、正常発達が歪 曲、阻害されていた。7歳（小2）頃から徐々に好転し 始め、11歳 (小 5 ) から 12 歳 6 力月（中 1 ）頃が本児と しては最良の状態で、かなりの伝達的言語もあり、感情 接触も相当好転、特異行動なども減少し、学校集団への 順応状態がかなり改善されていたが、その後相当急激に 症状が全般に悪化し、特に同一性保持の強迫的固執、内 的興奮、易刺激性、暴力行為などの増加、感情接触性の 減退が著しく、向精神病薬の調節、短期間の精神病院入 院（2 回）にもかかわらず、学校生活を続けることが極 めて困難となり、辛うじて中学部を終えた後、医療と生 活指導を主とする精神薄弱者更生施設においての生活を 引続き余儀なくされている。施設入所後も病状は中々好 転せず、薬量の増量による眠気のためもあって、基本的 生活習慣の維持すら困難な数年間を経た。しかし徐々に 好転し、20歳頃よりは薬量もやや減じることができ、弧 立的ではあるが中・軽度棟の生活に最低の順応が可能と なっている。この精神病的経過中幻覚、妄想などは認め られない。現在の服薬内容は 1 日量カルバマゼピン 600

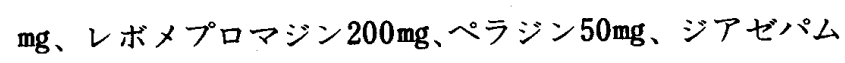

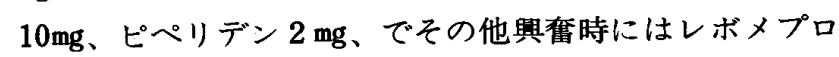
マジン100mgを屯用させている。これは抗てんかん剤、向 精神病薬とも相当量が維持量として使用されていること になる。

以上が本児のやや巨視的な経過であるが、次に1)言語、 2 )对人的行動（言語以外）、3)興味の偏在・固執性など、
4) 興奮衝動性、攻撃行動、5)知的機能、6)運動機能など の諸項目に分けて、多少の重複を省みず詳述する。

1) 言語：始語 1 歳児頃で比較的よくしゃべり語いも大 体順調に増加していたが、2 歳半ば頃から変調をきたし、 相手の言葉は大体理解するが、話しことば（自発語、応 答とも) 及び語いが減少してきた。この状態は附盖入学 後徐々に改善され、簡単な対話が可能となった。しかし、 12歳半より崩れ始め、自己の気にかかる事柄に関して短 い言葉で執拗に質問を繰返し（この場合、納得できぬと 興奮して暴力を振るうことが多い)、それ以外の話しこと ばは極めてそしくなった。これは施設入所後も大した変 化なく、小康状態が続いている現在においても大体同様 である。言語理解は、まず充分に存在しており、文字言 語に関しては話しことばよりかなり水準が高かった。なお 本児15１6歳頃より独笑、独語があったが、反響言語、遅延 反響言語が経過中全く認められなかったことは興味深い。

2) 言語以外の对人的行動：既述のように、幼児早期の 社会性の発達は大体順調で感情接触もほぼ普通と思われ ていたが、2 歳半頃より言語面などと平行して崩れ始め、 弧立の様相を深めてきた。しかし、小学校時代には漸次 感情接触も改善傾向を示し、全体像の最良であった11歳 〜12歳半ば頃には特定の友人に親しみを持って自発的に 働きかけること、相手の表情を見ながら素直に行動する ことなども認められ、クラスの集団行動にも大体従って いた。この時期を最良とし、その後、既述のごとくかな $\eta$ 急激な全般的病的増悪過程が進行し、施設入所後も中 中改善しなかった。20歳頃より幾分好転、最良時の状態 よりかなり低下した水準で大体固定し、自己のぺースを 変えず、弧立しながら集団の生活に最低の順応をしてい る。

3) 興味の偏在、固執性、その他の特異行動など：これ らはある程度関連・重複していて明瞭に区別することが できないが、まず興味の偏在に近いものを挙げる。巻き 尺を離さない（1 歳過～ 5 歳、離させると不安を示す)、 水遊び（1 歳半一 15歳）、高所登り（6歳頃）、煙、汽車 (9-10歳)、ブランコ、三輪車、ボール投げ、自転車 (10歳頃)、自動車 (14歳頃)と移り変わり、現在では全般 に無関心で特別な興味の对象はなく新しい事態にわずか に反応する程度である。

次は強迫的固執性が主であると考えられるものを列挙 する。バスの特定席 ( 6 歳頃)、特有な角張った字体で書 いては消し、消してはまた書く行為を繰り返す（７歳一 現在)、予定変更を承服しない（11歳〜現在）、物の位置、 状態の保持（12１5歳）、自己の生活パターンに对する固 執 (幼児期一現在)。大体以上の通りであり、持続期間の 長いものは時期により強度に変動があったことは言うま 
でもない。特に水遊じに関しては低年秢の時に特に強く、 厳冬の小川に入って終日遊んだことさえあった。またパ ターンへの固執に関連し、予定変更に对するこだわりが 異常に強く、なかなか承服しないのみならず、月余を経 て突然想起して変更時の事態を再現することさえあった。 本例の固執性は自閉症候群の中でも強度で特異的である と言えよう。その他の特異行動として、ところ構わず唾 を吐く神経性習癖行動（6１0歳）があり、感情の不安 定な時に多発した。全体像が悪化し始めた13歳前より左 耳款をかきむしって出血させるなどの自傷行為が出現し、 これは現在でもごくまれに認められる。

4) 興奞衝動性、攻撃行動など：5〜6 歳頃突然泣き出 し、1〜2 分もするとニコニコするという了解不能の感 情易変性が存在した。6 7 歳頃、バスの同乗者、友人 などを突然䠛んだり吒いたりするような原因不明の暴力 行為があった。その後自己の意に反することがあると暴 力を振い始めた。この暴力行為の起きるのは、自己の意
図が阻止された場合が大部分で、とくに自分の問いかけ に納得のいく答えが与えられなかった時が多かった。大 きく把之ると自己の独特のパターンが結果として阻止さ れた場合と言えよう。中学時代においては、原因から相 当な時間を経て本人が想起した時突然背後から器物で襲 う形式と激烈さが目立っており、出現時期を予測するこ とが困難で、この特異な遅延性攻撃行動に対し適切な对 処、指導法を見出しえなかった。その後施設に移って後、 このパターンを含めて攻撃行動が漸減し、現在では年に $2 \sim 3$ 回即時攻撃が存在する程度になっている。

5) 知的機能：WISCによるIQは12歳 4 力月時全 $59(\mathrm{~V}$ 57、 $\mathrm{P} 72$ )、14歳 2 力月時全50（V51、P 62）であり大体 軽度精神漣滞に相当する。学力面では比較的状態の良か った12歳頃には漢字混じりの文章を正確に読み、助言が あれば簡単な作文も書き、3〜4 位数の加減計算もでき たが、抽象的思考の面では劣っていた。参考までに12歳 4 力月のWISCの内容と 23 歳 10 力月のWISCの内容とを

Table 1.

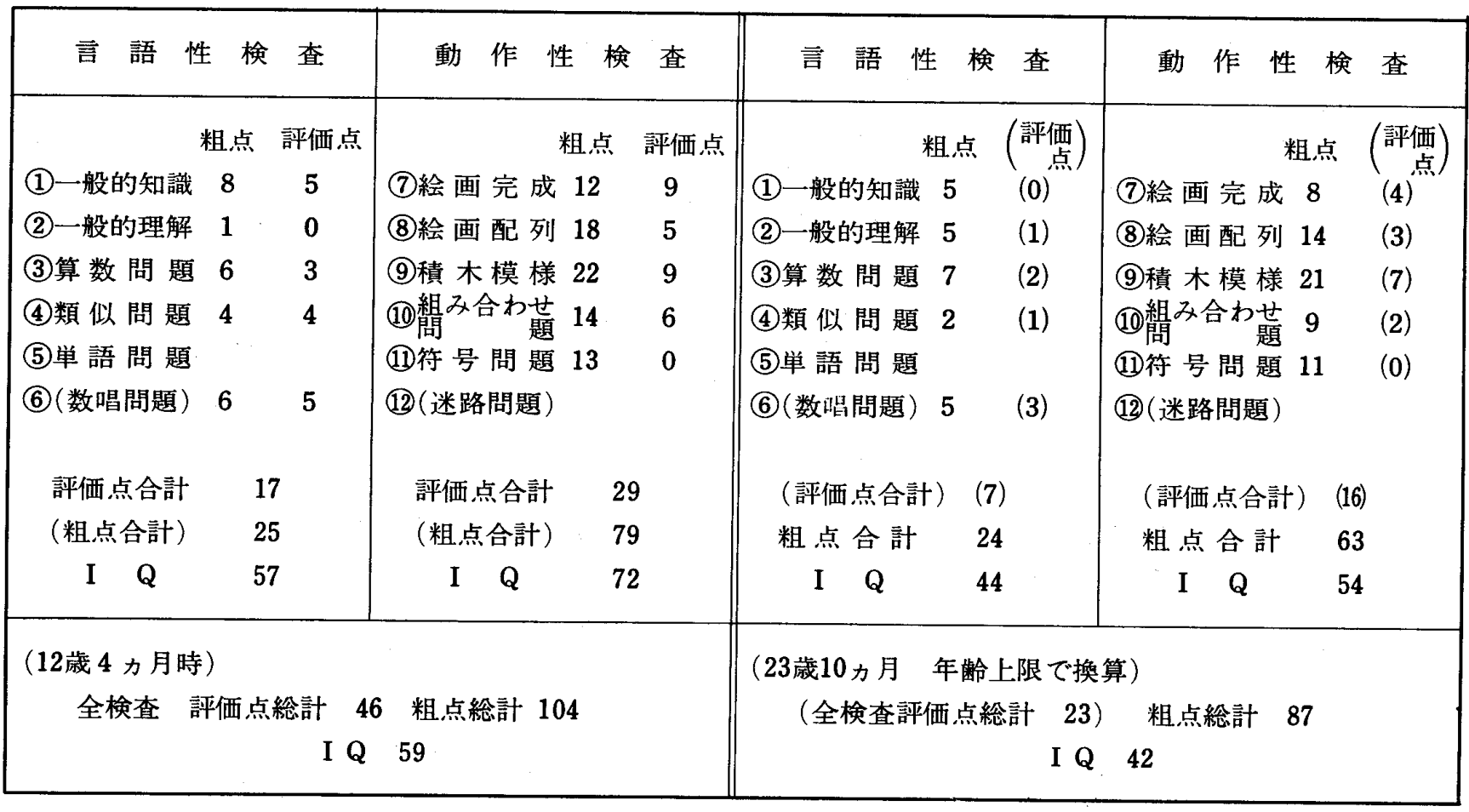

示しておく。

正確さを期するため、いずれもWISCを使用し（後者 は年齢超過のため）粗点で比較することにする。後者で は言語性でー 1、動作性ではー16、粗点綕計でー 17 とな ク、後者を年齢上限で換算した全 I Q は 42である。これ は明らかに低下しており、動作性の低下の方がより大で ある。
6)運動機能など：運動機能に関しては本質的には水準 以上と推定される。すなわち 6 㱓頃鉄棒など、7 葴頃ジ ヤングルジムなどを器用にこなし、13歳頃キャッチボー ル、キックなども技能が高かった。ただし全力を発揮す ることが少なく、技能習得意欲も不安定なため、潜在能 力は顕現した技能より高いと考えられる。 


\section{III 考 案}

本例の脳器質的変化の存在は II(2)で述べた脳波・C T 所見、てんかん発作などにより確実であり、その原因と しては臍帯捲絡、軽度仅死などの周産期の問題が最も疑 わしい。本児は出生 7 力頃より始まったてんかんを除 き身心とも表面上比較的順調に成熟発達していたが、巻 き尺（1歳過より)、水遊び（18力月頃より）に対する異 常固執性が気づかれており、30力月頃より言語、対人接 触をはじめ精神機能全般に自閉的退行、すなわち折れ線 型の経過が自然に始まった。折れ線型は経過不良のもの が多いとされているが、本例は漸次改善し11歳～12歳半 頃が最良の状態となり、当時においては感情接触性はか なり良く、伝達的言語の水準も相当高く、WISC全 $59(\mathrm{~V}$ 57、P 72）で、軽度精神遅滞のレベルであった。折れ線 型経過と処遇との関連も明瞭ではない。本例の発症は遅 くとも異常固執性の出現した 1 歳過ぎと推定され、30力 月頃より折れ線型経過が始まり、弧立、言語障害、強迫 的固執性などの自閉症状が明瞭となり、Kannerの記述、

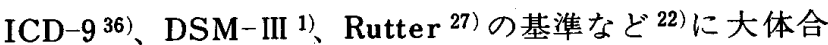
致し、自閉症に含まれることは是いもない。折れ線型に 対し、石井 ${ }^{12)}$ は 2 歳以前と簡単に述べており、若林 ${ }^{31)}$ は 30 力月〜 6 歳頃までに発生した数例も含めている。折れ 線発現が 30 力以後の場合、発症時期の点で自閉症の諸 基準から外れることになるが、この30力月以前の発症と いう基準は余り本質的なものとは思われない。初発が見 逃されることもあり、それが事実 30 力後であっ たとしても内在過程には実質的差はないと考えられる。 この点に関連し栗田 ${ }^{21)}$ は不統合精神病 $\left(\right.$ ICD-9 ${ }^{36)}$ )、小児 期に発症する全般的発達障害 (DSM-III $\left.{ }^{1)}\right)$ との異同を論 し、折れ線型自閉症との質的連続性を認めているが当然 と考えられる。

本例の最も特異な点は12歳半過ぎより再び出現した精 神病的過程であり、向精神病薬の調節、処遇上の配慮も 著効を奏せず、長い経過の後に次第に鎮静し、最良時よ りかなり低い水準で精神薄弱者施設の一般棟において孤 立しながら最低の順応をしている。しかも相当多量の服 薬継続という条件下の平衡であり、服薬中止により増悪 する可能性も存在する。この場合にも心因関与はまず否 定できる。本過程は単純型に精神運動性興奮の加わった 慢性分裂病様病像に近く、思春期に発した慢性折れ線様 病像とも表現できよう。本例は生後 7 力頃よりけいれ ん発作が発現し、その後発作型は不変である。規則的服 薬により 6 歳頃以後発作は抑圧されているが、脳波上、 背景波の徐波性異常と棘徐波結合を含む発作性異常とが 常に存在した。しかし、明瞭な非対称や焦点は終始存在 せず、精神運動発作、精神発作、意識減損発作なども一
貫して認められていない。従って本例は症状性てんかん ではあるが、発作型と脳波所見とより側頭葉てんかんと するには根拠がそしい。現在 C T 所見として認められる 側頭深部の病変は、それ以外の未証明の病変の存在を排 除するものではなく、 $\mathrm{C} \mathrm{T}$ 上の病巣と脳波所見との関連 が明らかでない現時点では、側頭深部の病巣とてんかん との関係も不詳とすべきであろう。次に折れ線型過程の 本質は現在解明されておらず、本例の場合にも、後に C $\mathbf{T}$ 上発見された非進行性と推定される病巣との関連は不 明である。また思春期に発症した慢性分裂病様病像と、 てんかんの分裂病様病像とを文献的に比較検討したが、 両者間には、病像、経過などに異なる点が多い。本例の 異常体験の欠如、挿間性動摇の次穴) と見なし難いことなどを、相異点の例として挙げておく。 しかし本過程と症状てんかんとの関係を完全に否定する ものではない。本例には軽度の分裂圈の負因があるが、 本例の病像は既述のように分裂病として最も診断し難い 病型であり、脳器質性が明瞭な症状てんかんでもあり、 思春期より分裂病が併発したと考えることは相当無理が あろう。しかし病像形成的関与を否定するものではない。 結局暫定的に、非定型または混合性器質脳症候群（DSM -III 1))とでもしておくべきであろう。不完全寛解時のW ISCで、あの程度の低下は、本病的過程の本質が何んで あれ、発現して差し支えないと考える。次に気分易変性、 多動性、攻撃性、興奮性、衝動性などは、Strauss 症候 群の行動特性とされている。本例の多動性、興奮衝動性、 感情易変性 $(5-6$ 歳頃最強)、原因不明の発作的暴力行 為 $(6-7$ 歳頃強度)、遅延性攻撃の激烈さなどは、シュ トラウス症候群でもあり、自閉症に多い症状（診断規準 以外ではあるが）でもあり、本例の器質的背景と相応す るものであろう。従って自閉症とシュトラウス症候群の 臨床像には部分的共通性が認められる。またかなりの言 語水準に達している本例において、その全経過を通じて 反響語、遅延反響語が全く認められなかった点はかなり 珍らしく、中学時代において最も強かったパターン阻止 に関連した遅延性攻撃行動は、はなはだ特異で他に類を 見ないものであろう。なお本例の固執性は既述のように 自閉症のうちでも最強度のものであることを指摘してお く。以上を紷合すると本症は症状、経過の両面において 特異な点が多く、それがかえって自閉症の本態解明に資 するものと考えられる。今後もその経過を追跡する予定 である。

\section{IV.まとめ}

脳器質的背景の明瞭な成人に達している自閉症の経 過を長期に追跡して、その症状、経過の特異性を明らか 
にし、脳波・C T所見などを踏まえてこれらを脳症理・ 精神病理の両面より考察した。指摘し得た諸点は次のと おりである。

(1)生後 7 力月に発症したけいれん発作のみの臨床的て んかんの発作は服薬により 6 歳以後抑圧されている。

(2)一貫して脳波上連続性・発作性異常があり、C T上 左側頭深部に高吸収巣を認める。

(3)左側頭葉深部の病巣とてんかんとの関連は不詳であ ク、発作型、脳波所見などより本例を側頭葉てんかんと するには無理があることを述べた。

(4)折れ線型経過及び思春期に発生した特異な慢性分裂 病様過程と、症状てんかん、脳病理所見、分裂圈の負因 などとの関係について考察した。

(5)多動性、感情易変性、発作的暴力行為などをシュト ラウス症候群と自閉症候群との連続線上に定位した。

(6)反響語、遅延反響語の欠如、最強度の固執性、遅延 性攻撃行動などの特異性について述べた。

(7)最良時の知的機能は軽度精神遅滞の水準（WISC 全 IQ59）であったが、現時点ではかなり低下したレべルで 平衡を保っている。

\section{【付 記〕}

稿を終えるにあたり、資料の収集に御協力を預いた岡 山県総合社会福祉センターの皆様に深謝致します。なお 本研究の要旨は第20回特殊教育学会において発表した。

\section{文献}

1) American Psychiatric Associaiton (1980): Diagnostic and Statistical Manual of Mental Disorders. 3rd ed. D.C., American Psychiatric Association.

2) Bartak, L., Rutter, M. \& Cox, A. (1975): A comparative study of infantile autism and specific developmental receptive language disorder. Brit. J. Psychiat., 126, 127-145.

3) Bemporad, J.R. (1979): Adult recollection of a formerly autistic child. J. Autism Develop. Disord., 9, 179-197.

4) DesLauriers, A.M. (1978): The cognitive-affective dilemma in early infantile autism: The case of Clarence. J. Autism Child. Schizo., 8, 219232.

5) DeMyer, M. K., Barton, S., DeMyer, W. E., Norton, J.A., Allen, J. \& Steele, R. (1973): Prognosis in autism: A follow-up study. J.
Autism Child. Schizo., 3, 199-246.

6) Eisenberg, L. \& Kanner, L. (1956): Early infantile autism, 1943-1955. Amer. J. Orthopsychiat., 26, 556-565.

7) Eisenberg, L. (1956): The autistic child in adolescence. Amer. J. Psychiat., 112, 607-612.

8) Fenton, G.W. (1981): Psychiatric disorders of epilepsy: Classification and phenology. In E.H. Reynolds \& M.R. Trimble (ed.): Epilepsy and Psychiatry. Churchill Livingstone, 12-26.

9) 細川 清(1966)：分裂病様病像を有するてんかん の臨床的研究, 精神経誌., 68(9)，1111-1137.

10) 細川 清(1982)：分裂病像と脳波異常, 臨床精神 医学, 11(4), 459-467.

11) 細川 清 (1982)：精神症状と脳波, 臨休脳波, 24 (2), 93-100.

12) 石井高明 (1971)：幼児自閉症の診断と治療, 日本 医事新報, No.2459，27-30。

13）石井高明 (1978)：自閉症の長期子後, 臨床精神医 学, 7(8), 907-912.

14）伊藤隆二 (1979)：シュトラウス以後の脳障害児研 究, 精神薄弱児研究, 247, 74-81.

15）伊藤隆二 (1981)：学習障害の基本概念について, 発達障害研究，3(2)，81-95.

16) Kanner, L. (1943): Autistic disturbances of affective contact. Nerv. Child, 2, 217-250.

17) Kanner, L. \& Baltimore (1951): Irrelevant and metaphorical language in early infantile autism. Amer. J. Psychiat., 103, 242-246.

18) Kanner, L. \& Baltimore (1951): The conception of wholes and parts in early infantile autism. Amer. J. Psychiat., 108, 23-26.

19) Kanner, L., (1971): Follow-up study of eleven autistic children originally reported in 1943. J. Autism Child. Schizo., 1, 119-145.

20) Kanner, L., Rodriguez, A. \& Ashenden, B. (1972): How far can autistic children go in matters of social adaptation. J. Autism Child. Schizo., 2, 9-33.

21) 栗田 広 $(1982) ： 2$ 歳以後より 5 歳までに, 精神 発達の崩壊を示した 9 児童例-“折れ線型自閉症” との関係について-, 精神医学, 24(9), 939-948.

22) National Society for Autistic Children (1978): Definition of the syndrome of autism. J. Autism Child. Schizo., 8, 162-170. 
23）小澤 熏 (1969)：幼児自閉症の再検討 $(2)$ - 疾病論 についてー，児精医誌.，10(1)，1-31。

24) Rutter, M. \& Lockyer, L. (1967): A five to fifteen year follow-up study of infantile psychosis-1. Description of sample. Brit. J. Psychiat., 113, 1169-1182.

25) Rutter, M. Greenfield, D. \& Lockyer, L. (1967): A five to fifteen year follow-up study of infantile psychosis-11. Social and behavioural outcome. Brit. J. Psychiat., 113, 1183-1199.

26) Rutter, M. \& Bartak, L. (1971): Causes of infantile autism: Some consideration from recent research. J. Autism Child. Schizo, , 1, 20-32.

27) Rutter, M. (1978): Diagnosis and definition of childhood autism. J. Autism Child. Schizo., 8, 139-161.

28) Strauss, A.A. \& Lehtinen, L.E. (1947): Psychopathology and education of the brain-injured child. Grune \& Stratton. (伊藤隆二 - 角本順次訳 (1979): 脳障害児の精神病理と教育, 福村出版.)

29) Toone, B. (1981): Psychosis of epilepsy. In E.H. Reynolds \& M.R. Trimble $\left(\mathrm{ed}_{\mathrm{o}}\right)$ : Epilepsy and Psychiatry. Churchill Livingstone, 113-137.
30) Treffert, D.A., McAndrew, J.B. \& Dreifuerst, P. (1973): An inpatient treatment program and outcome for 57 autistic and schizophrenic children. J. Autism Child. Schizo., 3, 138-153.

31）若林慎一郎 (1974)：幼児自閉症の折れ線型経過に ついて，児童医誌。, 15(4)，215-230.

32) 若林慎一郎 $(1980)$ : 幼児自閉症の予後, 精神医学, 22(3), 244-260.

33）若林慎一郎 (1980): 自閉症と言語, 発達障害研究, 2(1), 19-27.

34) Wing, L. \& Wing, J.K. (1971): Multiple impairments in early childhood autism. J. Autism Child. Schizo., I, 256-266.

35) Wing, L. (1976): Early childhood autism: Clinical, educational and social aspects. 2rid edition. Pergamon Press. (久保紘章・井上哲雄監訳 (1977) : 早期小児自閉症, 星和書店.)

36) World Health Organization (1978): Mental disorders: Glossary and guide to their classification in accordance with the Ninth Rivision of the International Classification of Diseases. WHO. 


\title{
A STUDY OF AN UNUSUAL CASE OF AUTISM WITH MENTAL RETARDATION
}

\author{
SEIGO USUI, YASUO HIRAI, JUNKO KOMOTO
}

(Okayama University)

The examination of typical and atypical cases of infantile autism for which intensive follow-up studies have been performed over a long period of time should be of value for the study of autism.

This is a report on an unusual case of autism with obvious cerebral organic signs observed from infancy to 24 years of age.

The neuro-and psychopathological findings of this case are as follows;

1) Clinical seizures which began at 7 months of age, have been under complete control by anticonvulsants since 6 years of age.

2) The EEG always revealed spike-and-slowwave complexes and slow dysrrhythmia in basic activity but showed no clear-cut evidence of focal sign. CT scanning, however, revealed high-density foci in a deep site of the left temporal lobe.

3) A correlation between the clinical seizures and the foci in the deep site of the left temporal lobe remains unknown and the possibility of temporal-lobe epilepsy of this case was not substantiated because the clinical seizure pattern and the EEG pattern of abnormality do not match well with the definition.

4) A survey of the literature on the correlation between the neuropathological findings and clinical courses of infantile autism such as a refraction of early developmental pattern and/or chronically schizophrenia-like state from puberty to the present time was made, from which no understandable conclusion was obtained.

5) Such behaviors as mood-lability and impulsive violence in early school years in this case appeared similar to the behavior-pattern of Strauss syndrome. Therefore the possibility of a partial continuity of the clinical pictures of infantile autism and of Strauss syndrome was proposed.

6) We noted some unusual characteristics of this case for infantile autism; the lack of echolalia and of delayed echolalia with the presence of a severe degree of repetitiveness and of delayed violence.

7) A mild degree of mental retardation was found (IQ 59, WISC) at best, but that is far below the score at present. 